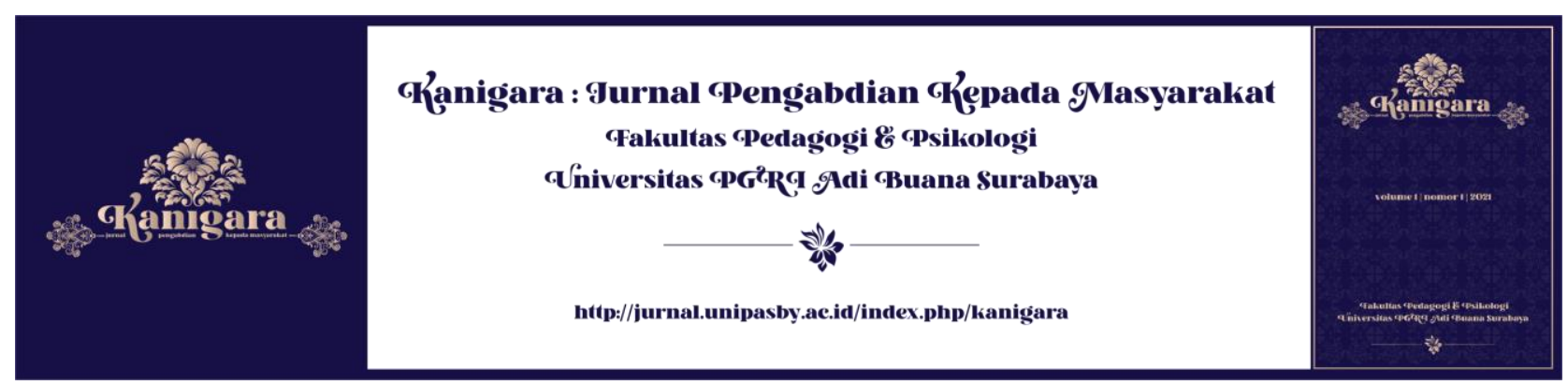

\title{
PELATIHAN STRATEGI PENGEMBANGAN KETERAMPILAN SOSIAL BAGI ANAK BERKEBUTUHAN KHUSUS DI KELOMPOK KKG PK-LK KABUPATEN JOMBANG
}

\author{
Muhammad Nurrohman Jauhari*1, Sambira², Angga Damayanto ${ }^{3}$ \\ 1,2Program Studi Pendidikan Khusus Universitas PGRI Adi Buana \\ 3 Program Studi Pendidikan Khusus - Universitas Negeri Yogyakarta \\ *Email: mnjauhari@unipasby.ac.id
}

\begin{tabular}{l}
\hline Informasi Artikel \\
\hline Kata kunci: \\
Keterampilan sosial, \\
Guru, Anak \\
berkebutuhan khusus
\end{tabular}

Diterima: 28-12-2020

Disetujui: 20-01-2021

Dipubikasikan: 25-012021

\begin{abstract}
Abstrak
Mitra dalam program pengabdian kepada masyarakat ini adalah Kelompok Kerja Guru (KKG) SDLB, SMPLB, SMALB di Kabupaten Jombang. Kegiatan ini berlangsung di SLB Cendekia Jombang. Total jumlah guru yang diberikan pelatihan adalah sejumlah 40 guru. Masalah yang dihadapi oleh guru di SLB adalah masih kurangnya keterampilan guru dalam menerapkan strategi pengembangan keterampilan sosial pada Anak Berkebutuhan Khusus (ABK). Solusi yang diberikan dalam program pengabdian kepada masyarakat ini adalah berupa pelatihan tentang strategi pengembangan keterampilan sosial pada ABK. Pelatihan merupakan salah satu cara untuk meningkatkan keterampilan seseorang dalam bidang tertentu. Pelatihan ini berfokus pada strategi pengembangan keterampilan sosial pada ABK. Pelatihan ini disampaikan dalam bentuk ceramah, studi kasus penyelesaian masalah, dan praktik cara penanganan ABK melalui simulasi peer teaching. Pelaksanaan pengabdian kepada masyarakat ini terdiri dari 3 tahap, yaitu: (1) persiapan (meliputi: koordinasi dengan KKG Jombang dan penyusunan materi pelatihan), (2) pelaksanaan (meliputi: pelatihan dan pendampingan), dan (3) evaluasi. Hasil dari pelatihan tersebut guru KKG dapat mengetahui pelaksanaan strategi keterampilan sosial bagi anak berkebutuhan khusus.
\end{abstract}

\begin{abstract}
Abstact
Partners in this community service program are the SDLB, SMPLB, and SMALB Teachers Working Group (KKG) in Jombang Regency. This activity took place at SLB Cendekia Jombang. The total number of teachers who were given training was 40 teachers. The problem faced by teachers in special schools is the lack of teacher skills in implementing social skills development strategies for children with special needs (ABK). The solution provided in this community service program is in the form of training on strategies for developing social skills for children with special needs. Training is one way to improve one's skills in a particular field. This training focuses on strategies for developing social skills for children with special needs. This training is delivered in the form of lectures, problem solving case studies, and practices on how to handle children with special needs through peer teaching simulations. The implementation of this community service consists of 3 stages, namely: (1) preparation (including: coordination with the Jombang KKG and preparation of training materials), (2) implementation (including: training and mentoring), and (3) evaluation. The results of the training, KKG teachers can find out the implementation of social skills strategies for children with special needs
\end{abstract}




\section{PENDAHULUAN}

Mitra dalam PPM (Program Pengabdian kepada Masyarakat) ini adalah Kelompok Kerja Guru Pendidikan Khusus Layanan Khusus (KKG PK-LK) yang berada di kabupaten Jombang. KKG-PKLK merupakan kelompok kerja guru yang bertugas di Sekolah Luar Biasa (SLB) di Kabupaten Jombang. Kelompok kerja guru tersebut sering mengadakan pertemuan yang dinamakan FKKG (Forum Kelompok Kerja Guru), pada setiap pertemuan tiap SLB mengirimkan 2 perwakilan untuk mengikuti kegiatan FKKG. Tujuan diadakannya FKKG yaitu untuk membahas permasalahan yang ada di setiap SLB di Kabupaten Jombang agar dapat merumuskan solusi pemecahan masalah yang ada disetiap SLB. Tahapan pelaksanaan FKKG dibagi menjadi 4 langkah, yaitu: a). pertemuan atau koordinasi untuk mengidentifikasi permasalahan; b). Observasi atau kunjungan dilaksanakan 8 kali dalam 1 tahun. Pelaksanaan kunjungan dilakukan oleh 2 orang perwakilan anggota forum, kegiatan tersebut dimaksudkan untuk mengetahui permasalahan dilapangan; 3). Mengkaji hasil observasi untuk dilaksanakan tindak lanjut. 4). Tindak lanjut, pada tahapan tindak lanjut FKKG akan mengadakan pelatihan atau workshop untuk mengatasi masalah yang dihadapi di SLB di Kabupaten Jombang.

Berdasarkan analisis situasi, dapat dirumuskan bahwa permasalahan mitra adalah sebagai berikut. (1) Banyak siswa berkebutuhan khusus yang memiliki hambatan sosial : Dari hasil observasi atau kunjungan yang dilakukan oleh perwakilan KKG terdapat banyaknya permasalahan sosial yang dialami oleh siswa berkebutuhan khusus di sekolah-sekolah SLB yang berada di Kabupaten Jombang (2) Kurangnya pengetahuan guru dalam mengembangkan keterampilan sosial bagi anak berkebutuhan khusus : Dari hasil observasi yang dilakukan oleh perwakilan KKG terdapat banyak guru SLB yang kurang mengetahui tentang cara mengembangkan keterampilan sosial bagi anak berkebutuhan khusus, kurangya wawasan guru tentang model dan strategi pembelajaran dalam menerapkan kepada siswa berkebuuhan khusus Sukirman, S. (2020).

Sesuai dengan permasalahan mitra yakni kurangnya keterampilan mengembangkan keterampilan sosial bagi anak berkebutuhan khusus, solusi yang ditawarkan adalah berupa pelatihan dan pendampingan terhadap guru dalam mengembangan keterampilan sosial anak berkebutuhan khusus. Pelatihan diberikan karena pelatihan dianggap efektif dalam meningkatkan keterampilan guru, khususnya di bidang pengembangan keterampilan sosial anak berkebutuhan khusus.

Hal ini sesuai dengan pendapat Yuwono, I., Mirnawati, Kusumastuti, D. E., \& Rahmah, N. (2020) Keterampilan sosial adalah sejumlah tingkah laku yang dipelajari dan ditunjukkan oleh individu sebagai suatu kinerja dalam berinteraksi dengan orang lain pada lingkungan tertentu. 
Adapun dimensi dari keterampilan sosial adalah komunikasi, kerja sama, asertif, tanggung jawab, empati, keikutsertaan, dan control diri Pernyataan tersebut juga diperkuat dengan pernyataan Miftakhul Jannah. (2020). Keterampilan sosial merupakan hal yang penting untuk dikembangkan dan dibentuk pada siswa di tingkat pendidikan dasar, di mana pada usia sekolah dasar ini siswa mulai beradaptasi dengan lingkungan pembelajaran yang memungkinkannya untuk berinteraksi lebih sering dengan teman sebaya dan guru di sekolah

\section{METODE}

1. Tahapan Pelaksanaan

Secara skematis tahapan pelaksanaan program pengabdian kepada masyarakat ini digambarkan dibawah ini :
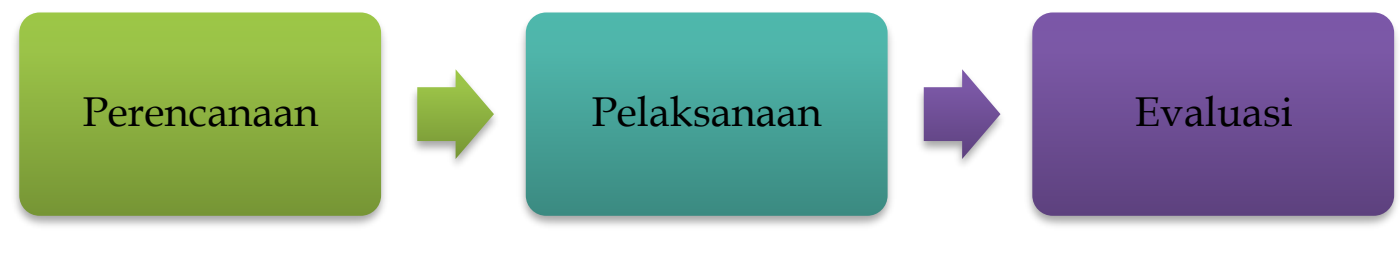

\section{Gambar 1. Tahapan pelaksanaan}

a. Tahap Persiapan

1) Koordinasi dengan Mitra

Agar pelaksanaan program berjalan dengan lancar, tim berkoordinasi dengan mitra yaitu Kelompok Kerja Guru Pendidikan Khusus Layanan Khusus (KKG PK-LK) yang berada di kabupaten Jombang. Adapun koordinasi yang dilakukan diantaranya mengenai jadwal pelakasanaan pelatihan, observasi dan pendampingan, tempat pelaksanaan dan alat pendukung yang dibutuhkan selama pelaksanaan PPM.

2) Penyusunan Materi Pelatihan cara mengembangkan keterampilan sosial bagi anak berkebutuhan khusus Setelah koordinasi dilakukan, selanjutnya tim merancang bahan materi yang akan diberikan saat pelatihan yaitu konsep dasar mengembangkan keterampilan sosial bagi anak berkebutuhan khusus dan metodologi pengembangan keterampilan sosial anak berkebutuhan khusus. Adapun materi yang akan diberikan dengan mempersiapkan FGD materi powerpoint. Setelah semua materi siap, selanjutnya tim mempersiapkan alat, bahan 
dan media yang dibutuhkan selama pelatihan. Dalam pelatihan dengan pertemuan tatap muka. media yang dibutuhkan diantaranya: LCD proyektor dan alat tulis.

b. Tahap Pelaksanaan

Setelah semua persiapan dan perlengkapan pelatihan telah siap, selanjutnya pelatihan dilaksanakan. Pelatihan dilaksanakan di aula SLB Cendikia Jombang dengan memberikan materi Pengembangan keterampilan sosial bagi anak berkebutuhan khusus pada Kelompok Kerja Guru Pendidikan Khusus Layanan Khusus (KKG PK-LK) yang berada di kabupaten Jombang. Pengabdian dilaksanakan selama 1 bulan. Adapun alat- alat yang dibutuhkan diantaranya LCD proyektor dan alat tulis

c. Tahap Evaluasi

Setelah pelaksanaan pelatihan, observasi, dan pendampingan, selanjutnya tim melakukan evaluasi atas serangkaian kegiatan yang dilaksanakan. Jika tujuan pelatihan belum tercapai, perlu dilakukan analisis untuk melihat mana yang perlu diperbaiki dan apa yang perlu dilakukan selanjutnya. Untuk memperoleh data tersebut, tim melakukan kegiatan Forum Group Discussion (FGD) dengan mitra. Pada forum ini, tim mengumpulkan informasi tentang manfaat dari kegiatan yang dilakukan, kendala, solusi serta membahas tentang keberlanjutan program yang akan datang Purnama, S. G. (2015).

\section{HASIL DAN PEMBAHASAN}

Langkah-langkah dalam pengabdian kepada masyarakat ini terdiri dari 3 tahap, yaitu: (1) persiapan, (2) pelaksanaan, dan (3) evaluasi. Berikut adalah rincian hasil yang dicapai dalam pengabdian kepada masyarakat ini :

\section{a. Perencanaan}

Persiapan pelaksanaan pengabdian kepada masyarakat terbagi menjadi (1) koordinasi dengan mitra dan (2) penyusunan materi pelatihan. Adapun rinciannya adalah sebagai berikut. Koordinasi dengan Mitra Agar pelaksanaan pengabdian masyarakat berjalan, tim berkoordinasi dengan Ketua Kelompok Kerja Guru Pendidikan Khusus Layanan Khusus (KKG PK-LK) yang berada di kabupaten Jombang. Adapun koordinasi yang dilakukan diantaranya mengenai jadwal pelakasanaan pelatihan dan pendampingan, tempat pelaksanaan dan alat pendukung yang dibutuhkan selama pelaksanaan pengabdian kepada masyarakat. 
Penyusunan Materi Pelatihan Setelah koordinasi persiapan dilakukan, selanjutnya tim merancang bahan materi yang akan diberikan saat pelatihan. Adapun materi yang akan diberikan adalah (1) konsep dasar pengembangan keterampilan sosial anak berkebutuhan khusus, dan (2) metodologi pengembangan keterampilan sosial anak berkebutuhan khusus. Adapun materi bahan yang disusun adalah materi powerpoint. Setelah semua materi siap, selanjutnya tim mempersiapkan alat, bahan dan media yang dibutuhkan selama pelatihan. Dalam media yang dibutuhkan diantaranya: LCD proyektor dan alat tulis

b. Pelaksanaan

Pelaksanaan pelatihan dilaksanakan di aula SLB Cendikia Jombang dengan memberikan materi Pengembangan keterampilan sosial bagi anak berkebutuhan khusus pada Kelompok Kerja Guru Pendidikan Khusus Layanan Khusus (KKG PK-LK) yang berada di kabupaten Jombang. Pelatihan terdiri dari 2 materi yaitu (1) konsep dasar pengembangan keterampilan sosial anak berkebutuhan khusus, dan (2) metodologi pengembangan keterampilan sosial anak berkebutuhan khusus

c. Evaluasi

Setelah pelaksanaan pelatihan, selanjutnya tim melakukan penilaian atas serangkaian kegiatan yang dilaksanakan. Tim melakukan evaluasi apakah pelatihan konsep dasar pengembangan keterampilan sosial anak berkebutuhan khusus dan metodologi pengembangan keterampilan sosial anak berkebutuhan khusus dapat meninkatkan keterampilan guru dalam mengimplementasikan kepada anak berkebutuhan khusus. Evaluasi dilaksanakan dengan menyelenggarakan Focus Group Discussion (FGD). untuk memperoleh interaksi data yang dihasilkan dari suatu diskusi sekelompok partisipan/responden dalam hal meningkatkan kedalaman informasi menyingkap berbagai aspek suatu fenomena kehidupan, sehingga fenomena tersebut dapat didefinisikan dan diberi penjelasan.

\section{KESIMPULAN}

Pelaksanaan Pelatihan Strategi Pengembangan Keterampilan Sosial Bagi Anak Berkebutuhan Khusus di Kelompok KKG PK-LK Kabupaten Jombang dilaksanakan secara kontinu dengan tahapan (1) persiapan, meliputi: koordinasi dengan mitra, penyusunan materi (2) pelaksanaan meliputi pelatihan, dan (3) evaluasi. Serta dapat meningkatkan keterampilan guru dalam mengimplementasikan keterampilan sosial bagi anak berkebutuhan khusus. 
Pelatihan Strategi Pengembangan Keterampilan Sosial Bagi Anak Berkebutuhan Khusus di Kelompok KKG PK-LK Kabupaten Jombang

\section{DAFTAR PUSTAKA}

Miftakhul Jannah. (2020). Studi Deskripsi : Perekonomian Orangtua Anak Berkebutuhan Khusus Terhadap Pendidikan Anak Berkebutuhan Khusus. SPECIAL : Special and Inclusive Education Journal, 1(1), 49-58. https://doi.org/10.36456/special.vol1.no1.a2293

Purnama, S. G. (2015). Panduan Focus Group Discussion (FGD) dan Penerapannya.

Sukirman, S. (2020). Efektivitas Kelompok Kerja Guru (KKG) dalam Peningkatan Kompetensi Guru. Indonesian Journal of Education Management \& Administration Review, 4(1), 201208.

Yuwono, I., Mirnawati, Kusumastuti, D. E., \& Rahmah, N. (2020). Pembelajaran Keterampilan Menjahit Dalam Mengembangkan Kemandirian Siswa Tunagrahita Ringan. SPECIAL : Special and Inclusive Education Journal,1(2), 154-161. https://doi.org/10.36456/special.vol1.no2.a2852 